\title{
HUKUM DAGANG DI INDONESIA
}

\section{Ekonomi Dan Bisnis Islam Universitas Islam Negeri}

\author{
Alauddin Makassar \\ Muhammad Mufthih Tsani
}

90500120128

\section{Muftitsani66@gmai.com}

\begin{abstract}
The purpose of this research is to analyze and see the trade law in Indonesia. Data collection techniques are in the form of document studies, namely examining documents related to the problem to be studied to obtain a theoretical basis and information in the form of formal provisions. Materials were analyzed using qualitative normative methods. The results of the study indicate that trade law is the entire legal rule that regulates the sanctions for human actions in their efforts to trade. The relationship between civil law and trade law can be seen from article 1 of the Criminal Code which reads: "The provisions of the place of law also apply to matters regulated in the Commercial Code, except for the Commercial Code itself which specifically regulates. In this connection there is a legitimate adage "Lex specialist derogat Lex generalis" which is a special law that trumps general law. Since the European Middle Ages (1000/1500) it has occurred in European countries and cities and at that time in Italy and Southern France has been born cities as trading centers (Genoa, Florence, Venice)

Keywords: law, trade law, Indonesia, KUHP, KUHD, KUHS
\end{abstract}

\begin{abstract}
Abstrak
Tujuan dari penelitian ini adalah untuk menganalisis dan melihat hukum perdagangan di Indonesia. Teknik pengumpulan data berupa studi dokumen, yaitu meneliti dokumen-dokumen yang berkaitan dengan masalah yang akan diteliti untuk memperoleh landasan teori dan informasi berupa ketentuanketentuan formal. Bahan dianalisis dengan menggunakan metode normatif kualitatif. Hasil penelitian menunjukkan bahwa hukum perdagangan adalah keseluruhan aturan hukum yang mengatur tentang sanksi perbuatan manusia
\end{abstract}


dalam usahanya melakukan perdagangan. Hubungan hukum perdata dengan hukum perdagangan dapat dilihat dari pasal 1 KUHP yang berbunyi:

"Ketentuan tempat hukum berlaku juga terhadap hal-hal yang diatur dalam KUH Perdagangan, kecuali KUH Dagang sendiri yang mengatur secara khusus. ." Dalam hubungan ini ada Adagium "Lex spesialis derogat Lex generalis" yang sah yang merupakan hukum khusus yang mengalahkan hukum umum. Sejak Abad Pertengahan Eropa (1000/1500) yang terjadi di negara dan kota-kota Eropa dan pada masa itu di Italia dan Prancis selatan telah lahir kotakota sebagai pusat perdagangan (Genoa, Florence, Vennetia)

Kata kunci: hukum, hukum perdagangan, Indonesia, KUHP, KUHD, KUHS

\section{PENDAHULUAN}

Sejak abad pertengahan eropa (1000/ 1500) yang terjadi di negara dan kotakota di Eropa dan pada zaman itu di Italia dan Perancis selatan telah lahir kotakota sebagai pusat perdagangan (Genoa, Florence, vennetia, Marseille, Barcelona dan Negara-negara lainnya ). Tetapi pada saat itu Hukum Romawi (corpus lurus civilis ) tidak dapat menyelsaikan perkara-perkara dalam perdagangan, maka dibuatlah hukum baru di samping Hukum Romawi yang berdiri sendiri pada abad ke-16 yang disebut hukum pedagang (koopmansrecht). Karena bertambah pesatnya hubungan dagang maka pada abad ke-17 diadakan kodifikasi dalam hukum dagang oleh mentri keuangan dari raja Louis XIV (1613-1715) yaitu Corbert dengan peraturan (Ordonnance DuCommerce) 1673. Dan pada tahun 1681 disusun Ordonnance De La Marine yang mengatur tenteng kedaulatan dan pada tahun 1807 di Perancis di buat hukum dagang tersendiri dari hukum sipil yang ada yaitu (Code De Commerce) yang tersusun dari Ordonnance Du Commerce (1673) dan Ordonnance Du La Marine (1838).

Pada saat itu Nederlands menginginkan adanya hukum dagang tersendiri yaitu KUHD belanda dan pada tahun 1819 drencanakan dalam KUHD ini ada 3 kitab dan tidak mengenal peradilan khusus. Lalu pada tahun 1838 akhirnya di sahkan. KUHD Belanda berdasarkan azas konkordansi KUHD belanda 1838 menjadi contoh bagi pembuatan KUHD di Indonesia pada tahun 18484. Dan pada akhir abad ke-19 Prof. Molengraaff merancang UU kepailitan sebagai buku III di 
KUHD Nederlands menjadi UU yang berdiri sendiri (1893 berlaku 1896)5. Dan sampai sekarang KUHD Indonesia memiliki 2 kitab yaitu, tentang dagang umumnya dan tentang hak-hak dan kewajiban yang tertib dari pelayaran. (Rahayu, 2008)

Perdagangan internasional merupakan salah satu bagian dari kegiatan ekonomi yang akhir-akhir ini mengalami perkembangan pesat. Perhatian dunia terhadap bisnis internasional juga semakin meningkat dengan semakin berkembangnya arus perdagangan barang, jasa, modal, dan tenaga kerja antar negara. Ruang lingkup hukum perdagangan internasional cukup luas dikarenakan sifatnya lintas batas. Pada awalnya hubungan perdagangan hanya terbatas pada satu wilayah negara tertentu, tetapi dengan semakin berkembangnya arus perdagangan maka hubungan dagang tersebut turut melibatkan para pedagang dari negara lain. Adapun kegiatan ekspor-impor didasari oleh kondisi bahwa tidak ada satu negara yang benar-benar mandiri karena satu sama lain saling membutuhkan dan saling mengisi. Setiap negara memiliki karakteristik yang berbeda, baik sumber daya alam, iklim, geografis, demografi, struktur ekonomi, dan struktur sosial. Sehingga dengan perbedaanperbedaan tersebut menyebabkan variasi komoditas yang dihasilkan. Maka dari itu, negara-negara perlu menjalin suatu hubungan perdagangan untuk memenuhi kebutuhan tiap-tiap Negara.

Secara mendasar, hukum perdagangan internasional lahir dari praktek para pedagang. Hukum yang diciptakan oleh para pedagang ini lazim disebut sebagai lex mercatoria (law of merchant). lex mercatoria tumbuh dari adanya empat faktor. Pertama, lahirnya aturan-aturan yang timbul dari kebiasaan dalam berbagai pekan raya. Kedua, lahirnya kebiasaan-kebiasaan dalam hukum laut. Ketiga, lahirnya kebiasaan-kebiasaan yang timbul dari praktek penyelesaian sengketa-sengketa di bidang perdagangan. Keempat, berperannya notaris dalam memberi pelayanan jasa-jasa hukum dagang. Pada tahap perkembangan ini, negara-negara mulai sadar perlunya pengaturan hukum perdagangan internasional, lantas mereka mencantumkan aturan-aturan perdagangan internasional dalam kitab undang-undang hukum. Adapun contohnya Perancis yang membuat Kitab UU Hukum Dagang (code de commerce) tahun 1807 dan Jerman yang. (Widjaja, 2000)

Secara khusus tahap ini muncul secara signifikan setelah berakhirnya Perang Dunia II. Salah satu perjanjian multilateral yang ditandatangani pada masa ini adalah disepakati lahirnya GATT tahun 1947. Ciri kedua dalam perkembangan 
di tahap ini yakni munculnya organisasi internasional. Salah satu badan yang menonjol adalah PBB, walaupun sebenarnya peran PBB di bidang perdagangan internasional tidak terlibat secara langsung. Akan tetapi, peran PBB di bidang ekonomi dan perdagangan termuat dalam Piagam PBB, yakni aturan tentang tujuan PBB yaitu mencapai kerjasama internasional antara lain meneyelesaikan masalah-masalah ekonomi internasional. Ciri ketiga dari tahapan perkembangan ini adalah disepakatinya pendirian badan-badan ekonomi regional di suatu kawasan region tertentu. Blok perdagangan regional yang mula-mula membawa pengaruh cukup luas adalah The European Single Market tahun 1982 dan blok perdagangan Amerika Utara.

Perdagangan telah lama menjadi aktivitas manusia, jauh sebelum berdirinya negara modern berdasarkan Perjanjian Westphalia 1648. Di Asia sendiri dikenal perdagangan menggunakan Jalur Sutera yang menjadi penghubung antara Timur Tengah-Asia Tengah-Tiongok. Eropa sendiri mulai mengenal aktivitas perdagangan dari tahun 1000-1500 Masehi, yaitu hukum yang berlaku adalah hukum Kerajaan Romawi. Pada abad ke-16 mulai muncul badan peradilan khusus untuk menangani sengketa terakit dengan perniagaan. Pada abad ke 17 Perancis mengeluarkan Code de Commerce, yaitu seperangkat peraturan yang mengatur perihal perdagangan di negeri tersebut. Melihat hal tersebut menandai pentingnya pengaturan hukum perdagangan oleh setiap negara. Sehingga dalam perkembangan hukum internasional, maka diperlukan seperangkat aturan hukum terkait dengan pengaturan regulai perdagangan internasional yang berlaku univresal. Pemberlakukan hukum perdagangan secara universal ini diharapkan dapat menguntungkan semua pihak dalam melakasankan aktivitasnya.

Hukum perdagangan internasional memiliki perbedaan dintinjau dari sifatnya, hukum perdagangan internasional mengatur mengenai hubungan perdagangan antar negara dengan pembatasan perkara secara perdata. Definisi tersebut menunjukkan dengan jelas bahwa aturan-aturan tersebut bersifat komersial. Dalam defenisinya ia menegaskan bahwa ruang lingkup bidang hukum ini tidak termasuk hubungan-hubungan komersial internasional dengan ciri hukum 
publik. Termasuk dalam bidang hukum publik ini yakni aturan-aturan yang mengatur tingkah laku atau perilaku negara-negara dalam mengatur perilaku perdagangan yang mempengaruhi wilayahnya . (Setiawan, 2000)

Dalam perkembangannya beberapa institusi internasional membentuk lembaga yang mengatur mengenai regulasi hukum perdagangan internasional. Diantaranya di prakarsai oleh Perserikatan Bangsa-Bangsa yang membentuk United Nations Conference on Trade and Development (UNCTAD). UNCTAD adalah organisasi internasional yang didirikan pada tahun 1969. UNCTAD adalah organ utama Majelis Umum PBB dalam menangani isu perdagangan, investasi dan pembangunan. UNCTAD beranggotakan 191 negara dan bermarkas di Jenewa, Swiss. UNCTAD mempunyai 400 petugas dan anggaran sebesar $\$ 500$ juta setahun. Selain itu juga dibentuk United Nations Commission on International Trade Law (UNCITRAL), ide pembentukkannya diadakan bukan karena inisiatif dari anggota negara barat, tetapi dari wakil tetap Pemerintah Republik Rakyat Hongaria yang telah mengusulkan kepada PBB agar dibentuk UNCITRAL berdasarkan ketentuan pasal 13 (e) dari Peraturan Sidang Umum PBB. UNCITRAL berdiri pada tanggal 17 Desember 1966 melalui Resolusi Majelis Umum PBB Nomor 2205 (XXI). UNCITRAL terdiri dari 60 negara anggota yang ditetapkan oleh General Assembly. Tugas utamanya adalah mengurangi perbedaan-perbedaan hukum diantara Negaranegara anggota yang dapat menjadi rintangan bagi perdagangan internasional.

Dalam praktek hukum dagang Indonesia permasalahan ini bukannya tidak penting. Sudah lazim seseorang atau satu pihak yang ingin memulai berkecimpung di dunia usaha menanyakan bentuk usaha seperti apakah yang cocok bagi mereka. Sarjana hukum tentu saja dituntut untuk dapat menjelaskan sistematika hukum dagang Indonesia kepada mereka. Dalam bahasa yang sederhana tentunya. Begitu juga apabila timbul pertanyaan akan keberadaan badan-badan hukum lain yang diakui oleh sistem hukum Indonesia.

Kepastian hukum atau tertib hukum tersebut hanya dapat terwujud apabila ada hukum tertulis atau undang-undang yang mengaturnya. Hanya saja, menurut beliau penyusunan kitab undang-undang hukum perdata dan kitab undangundang hukum dagang akan memakan waktu yang sangat lama. Untuk itu, ujarnya lebih lanjut, pilihan terbaik adalah dengan penyusunan produk perundangan secara sebagian demi sebagian, menurut urgensi masing-masing. (Nasima, 2005) 
Hukum dagang adalah ilmu yang mengatur hubungan antara suatu pihak dengan pihak lain yang berkaitan dengan urusan-urusan dagang.Definisi lain menyatakan bahwa hukum dagang merupakan serangkaian norma yang timbul khusus dalam dunia usaha atau kegiatan perusahaan.

Hukum dagang masuk dalam kategori hukum perdata, tepatnya hukum perikatan. Alasannya karena hukum dagang berkaitan dengan tindakan manusia dalam urusan dagang. Oleh karena itu hukum dagang tidak masuk dalam hukum kebendaan. Kemudian hukum dagang juga berkaitan dengan hak dan kewajiban antarpihak yang bersangkutan dalam urusan dagang. Hukum perikatan mengatur hal ini. Itulah sebabnya hukum dagang dikategorikan ke dalam hukum perikatan. Hukum perikatan adalah hukum yang secara spesifik mengatur perikatan-perikatan dalam urusan dagang.

Sengketa dapat bermula dari berbagai potensi sengketa, salah satunya yaitu pada sengketa perdagangan internasional (Huala Adolf, 2015)karena umumnya dalam perdagangan internasional melibatkan 2 (dua) negara, adanya perbedaan hukum dari negara tersebut yang saling berbeda satu dengan lainnya, maka benturan-benturan hukum antar negara yang terlibat tidak dapat dihindari.Perdagangan internasional adalah pertukaran midal, barang adan jasa melintasi batas-batas negara atau wilayah, industrualisasi, maju transportasi, globalisasi, perusahaan multinasional, dan outsourcingsemua memiliki dampak yang besar pada sistem perdagangan internasional. Perdagangan internasional merupakan sumber. (Restiyanda, 2018)

sengaja, para pihak menghendaki terjadinya akibat hukum. Namun demikian sering kali akibat hukum yang dikehendaki tersebut tidak berwujud. Hal ini yang mengakibatkan tidak terlaksananya akibat hukum karena adanya keenganan para pihak untuk melaksanakan prestasi atau bahkan kemungkinan adanya perbedaan pendapat para pihak terhadap hak dan kewajiban yang sebelumnya telah dirumuskan sendiri oleh mereka dalam perjanjian. 


\section{Hubungan Hukum Perdata dengan Hukum Dagang}

Hukum dagang adalah keseluruhan aturan hukum yang mengatur dengan disertai sanksi terhadap perbuatan manusia di dalam usaha mereka untuk menjalankan perdagangan. Hubungan antara Hukum Dagang dengan Hukum Perdata erat sekali, karena sebagian dari aturan-aturan Hukum Dagang terdapat dalam Buku III KUH-Perdata tentang Perikatan. Adapun yang dimaksud dengan perikatan adalah hukum yang mengatur hubungan hukum antara dua orang atau lebih yang di satu pihak menimbulkan kewajiban dan di pihak yang lain menimbulkan suatu hak. Hak dan kewajiban itu bersumber dari perjanjian misalnya jual-beli, asuransi, pengangkutan, makelar, komisioner, wesel, cheque, Firma, CV, PT dan sebagainya.

Rumusan pasal 1 di atas mencerminkan bahwa KUH-Dagang adalah hukum yang bersifat khusus sedangkan KUH-Perdata merupakan peraturan yang bersifat umum. Hal ini terjadi apabila suatu hal telah diatur dalam KUH-Dagang, maka ketentuan-ketentuan Hukum Perdata tidak diberlakukan, tetapi bila suatu hal tidak diatur dalam KUHD aturan itu terdapat dalam KUH-Perdata, maka ketentuan-ketentuan KUH-Perdata berlaku dalam hubungan hukum di bidang perdagangan yaitu dalam melakukan perjanjian-perjanjian yang menimbulkan hak dan kewajiban masing-masing pihak.

Dengan demikian, hukum dagang adalah bagian yang tidak terpisahkan dari hukum perikatan, karena hukum perikatanadalah hukum perjanjian yang terdapat baik dalam masyarakat umum maupun dalam perdagangan. Karena hukum perikatan adalah bagian dari hukum perdata maka hukum dagang adalah merupakan bagian dari hukum perdata, misalnya pasal 1319 KUH Perdata menentukan bahwa semua perjanjian yang bernama maupun yang tidak bernama harus tunduk pada ketentuan-ketentuan KUH Perdata. 
Demikian eratnya hubungan tersebut, sehingga ada beberapa pendata para sarjana hukum yang menggambarkan hubungan hukum perdata dengan hukum dagang, yaitu1:

1. Prof. Subekti, S.H., berpendapat:“Terdapatnya KUHP di samping, KUHS/KUH Perdata sekarang ini dianggap tidak pada tempatnya, karena sebenarnya "hukum dagang tidak lain daripada hukum perdata", dan perkataan dagang bukanlah suatu pengertian hukum, melainkan suatu pengertian perekonomian.Dengan demikian sudahlah diakui, bahwa kedudukan KUHD terhadap KUHS adalah sebagai hukum khusus terhadap hukum umum.

2. Prof. Sudiman Kartodiprojo, S.H., berpendapat:"Dengan perkataan lain KUHD merupakan lex specialis terhadap KUH Perdata, dan KUH Perdata sebagai lex generalis terhadap KUHD."

3.Prof. Soekardono, S.H., berpendapat:"Pasal 1 KUHD memelihara kesatuan antara hukum perdata umum dan hukum dagang, sekedar KUHD tidak khusus menyimpang dari KUHS."

Sementaraitu,terhadapKitabUndang-undangHukumDagang(Wetboek van Koophandel) dan Kitab Undang-undang Hukum Perdata (Burgerlijke Wetboek) masih menjadi rancangan untuk dirubah dan disesuaikan berdasarkankaidah,ide,nilaiyanghidupdalammasyarakatsebagaisebuahUndangUndang Karya Bangsa. Dimasukkannya KUHD dan KUHPerdata dalamProlegnas,merupakantantangan,karenakeduakitabundang-undang ini mengatur hubungan antara pihak dalam hukum keperdataan danperdagangan.Beberapaahlihukumdalamliteratur"HukumDagang",mengataka n bahwa hubungan antara KUH Perdata dengan KUHD sangat erat.HalinidapatdilihatdariisiPasal1KUHD,yang isinya sebagai berikut Lex 
Special Derogate Legi Generaliartinya hukum yang khusus KUHD mengesampingkan hukum yang umum KUH Perdata.

Letak hukum dagang dalam ruang lingkup hukum perdata ialah dalam hukum perikatan yang menjadi bagian dari hukum harta kekayaan selain hukum kebendaannya.Hukum dagang dimasukan ke dalam bagian hukum perikatan dan bukan dalam hukum kebendaan karena hukum dagang mengaturtindakantindakanmanusiadalamurusandagang,sehinggadengan sendirinya hukum dagang mengatur hak dan kewajiban antara pihak yang bersangkutan.Adapun hukum yang mengatur hak dan kewajiban antara para pihak itu adalah hukum perikatan

Dapatdikatakan,bahwasemangatuntukmelakukanpembaharuanhukum dagang di Indonesia adalah membangun hukum nasional untuk mengusahakankesatuanapabilamungkin,membolehkankeanekaragamanbilakead aanmenghendakinya,tetapibagaimanapunjugamengutamakankepastian.Melihat pada cerminan konsep negara hukum dalam Pembukaan UUD1945,makaasaslegalitasselaludikedepankan, artinya,segalabentukpembahar uan hukum selalu dibuat dalam bentuk tertulis untuk menjaga asas kepastian hukum.Letak atau posisi KUHD dalam sistem hukum di Indonesia tidak mempunyai kedudukan mengikat yang jelas.Meskipun telah tertulis,produkhukumberupa"KitabUndangUndangHukumDagang"hanyasebagaikumpulanperaturanperaturantertulissaja,sehinggaketikaterdapatketentuandibawahnyayangbertentan g/menyimpang,makatidakada kekuatan mengikat secara hukum untuk dibatalkan. 


\section{Daftar Pustaka}

Nasima, I. (2005). Hukum perdagangan indonesia. Ekonomi Syariah, 1(2), 7090.

Rahayu, S. (2008). Hukum Dagang Di indonesia. Ekonomi Syariah, 1(2), 80100.

Restiyanda, R. (2018). Penyelesaian Sengketa Dagang Internasional. Ekonomi Syariah, 1(2), 130-180.

Setiawan, M. A. (2000). Hukum perdagangan internasional. Ekonomi Syariah, 1(2), 100-120.

Widjaja. (2000). Sejarah Dan Perkembangan Pokok Aturan Hukum. Ekonomi Syariah, 1(2), 60-90. 